\title{
Evaluation of Antioxidant Capacities and Phenols Composition of Wild and Cultivated Berries
}

\author{
GABRIELA STANCIU1, SIMONA LUPSOR ${ }^{1 *}$, ANETA TOMESCU², RODICA SIRBU ${ }^{3}$ \\ ${ }^{1}$ Ovidius University of Constanta, Department of Chemistry and Chemical Engineering, 124 Mamaia Blvd., 900527, Constanta, \\ Romania \\ ${ }^{2}$ Ovidius University of Constanta, Faculty of Medicine, Ion Voda Str., 900525, Constanta, Romania \\ ${ }^{3}$ Ovidius University of Constanta, Faculty of Pharmacy, 124 Mamaia Blvd., 900527, Constanta, Romania
}

\begin{abstract}
The study presents original results concerning analytical characterization of alcoholic extracts of four wild berries (blueberries, blackberries, red currants and raspberries) and two cultivated berries (black cherries and strawberries). Total and some individual phenols concentrations were determined using molecular absorption spectrometry (modified Folin Ciocalteu method) and HPLC-DAD technique. The measurement of lipid-soluble antioxidant capacity $(A C L)$ was done by photochemiluminescence method using trolox as standard.The highest total phenolic content was registered in blueberries (543.5 mg/100g f.w.), while the lowest was found in raspberries ( $344.5 \mathrm{mg} / 100 \mathrm{~g}$ f.w.).HPLC - DAD analysis indicated the presence of six individual polyphenolic compounds in different concentrations: gallic acid (62.664 - $178.821 \mathrm{mg} / 100 \mathrm{~g} \mathrm{f.w}$ ); chlorogenic acid (30.152 - $243.923 \mathrm{mg} / 100 \mathrm{~g}$ f.w.); 3-0-methyl-gallic acid (2.035 - $4.907 \mathrm{mg} / 100 \mathrm{~g}$ f.w.); caffeic acid (0.401 - $5.664 \mathrm{mg} / 100 \mathrm{~g}$ f.w.); p-coumaric acid (4.252 - $10.806 \mathrm{mg} / 100 \mathrm{~g}$ f.w.) and cinnamic acid (0.665-0.958 mg/100 g f.w.). ACL results showed values between 54.00 and $1152 \mu$ mols trolox/100 g f.w.
\end{abstract}

\section{Keywords: berries, total phenols, antioxidant capacity of soluble lipids, HPLC-DAD chromatography}

It is well known that the consumption of controlled diets especially high in berries, such as blueberries, blackberries, red currants, raspberries, strawberries and black cherries, increases significantly the human body capacity in the maintenance of health and protection from coronary heart disease, cancer, combating of diabetes, degenerative diseases and protects human organisms against oxidative stress induced by free radical species [1-3].

The antioxidant capacity is mainly given by the content of phenolic compounds but also by the other compounds like minerals, vitamins, phenolic acids, tannins and flavonoids. Different phenolic compounds occur in different berries fruits and their relative concentrations and proportions may also vary. These differences affect the total antioxidant capacity and also influence the therapeutically effects $[4,5]$. Greater knowledge regarding the cultivars or provenance of berries fruits may influence their market value and also could provide healthier food diet products. This information could be important for pharmaceutical and food industry to decide which berries fruits products to use up and for consumers to decide which products to purchase.

The reduction reactions of free radicals is directly related with the antioxidant compounds contents and reflect the protective capacity for human body cell and tissue protection againstoxidative stress and also againstother biological effects associated with chronic diseases [6, 7].

Large number of studies suggest that there is a connection between regular polyphenols consumption and reduced risk of developing different types of cancer. Anticancer effect of polyphenols is given by their antioxidant properties which in fact protect DNA (RNA) nucleic acids against oxidative damages inflicted by carcinogenic substances $[8,9]$.

The main phenols in wild berries are anthocyanins, flavonols, hydroxycinnamic acid, ellagic acid, ellagic tannins (Rubus and Fragaria genus) and proanthocyanins which mean that berries have bioactive properties with an important capacity against oxidative stress of living cells.
Polyphenolic content of vegetable materials represents a significant interest due to their antioxidant potential and due to anti-inflammatory properties present at cell level [10]. Therefore, it is important to study there compounds activity and also to establish the optimal quantity which can be consumed best. Comparative characterization of the phenolic of wild berries (blueberries, blackberries, red currants, raspberries) versus cultivated berries (black cherries and strawberries) alcoholic extracts could give important information.

The aim of our study was to determine phenolic compounds through various methods for four alcoholic extracts of wild berries (blueberries, blackberries, red currants and raspberries) and two alcoholic extracts of cultivated berries (black cherries and strawberries) and to evaluate their antioxidant capacity of lipids (ACL). The total content of phenolic compounds was measured using the Folin-Ciocalteu method, the phenolic profile of studied extracts was established using high performance liquid chromatography HPLC-DAD and the lipid-soluble antioxidant capacity $(A C L)$ was evaluated by photochemiluminiscence method (PLC) using trolox as standard.

\section{Experimental part \\ Fruit samples}

Wild berries (blueberries, blackberries, red currants, and raspberries) collected from local forests and cultivated berries (black cherries and strawberries) brought from local producers from Dobrogea County, Romania have been analysed.

\section{Chemicals}

All used reagents were of analytical reagent grade. Gallic acid was purchased from Fluka (Buchs, Switzerland) and Folin - Ciocalteu reagent from Merck (Darmstadt, Germany). Gallic acid (standard phenolic compound) used as $10^{-2} \mathrm{~mol} \mathrm{LL}^{-1}$ solution was prepared by dissolving 376 $\mathrm{mg}$ of gallic acid in $100 \mathrm{~mL}$ of ethanol. Folin - Ciocalteu reagent was diluted with distilled water as 1:10 (V:V). 


\section{Sample extracts}

Extractions were achieved by maceration of $10 \mathrm{~g}$ of fresh berries samples in $100 \mathrm{~mL}$ ethylic alcohol $50 \%(\mathrm{~V}: \mathrm{V})$ at room temperature and protected from light during six days. All samples were filtered and analysed.

\section{Determinations and equipments}

Total phenolic contents (TPC) were determined according to the Folin-Ciocalteu method [10-14]. Total concentrations of phenolic in extracts were measured by molecular absorption spectrometry according to a colorimetric reduction of a phosphowolframatephosphomolibdate complex to blue products by soluble phenolic compounds, in sodium carbonate media. Spectrometric measurements were carried out using a UVVis Jasco V550 scanning spectrophotometer.

The absorbance of the coloured complex was measured at $675 \mathrm{~nm}$. The absorbance relative to a gallic acid standard curve was measured and results are expressed as gallic acid equivalents ( $\mathrm{mg} \mathrm{GAE} / \mathrm{L}$ ). All samples were performed in triplicate and the mean value was reported.

The total phenols content of berries was expressed as $\mathrm{mg}$ of gallic acid equivalents per $100 \mathrm{gram}$ of fresh weight (mg GAE/100g f.w.). A standard solution of gallic acid prepared as previously mentioned was used for calibration curve.

In a series of $50 \mathrm{~mL}$ volumetric flasks volumes of 0.5 ; 1.0; 1.5; 2.0; 2.5; 3.0 and $3.5 \mathrm{~mL}$ of gallic acid standard solution were introduced and were added $1 \mathrm{~mL}$ of FolinCiocalteu-reagent $1: 10(\mathrm{~V}: \mathrm{V})$ and $1 \mathrm{~mL}$ of $20 \%(\mathrm{w} / \mathrm{v})$ aqueous $\mathrm{Na}_{2} \mathrm{CO}_{3}$; after 10 min the volume was made up to $50 \mathrm{~mL}$ with distilled water. After another $30 \mathrm{~min}$. of incubation at $25^{\circ} \mathrm{C}$ the absorbance was measured at 675 $\mathrm{nm}$. The calibration curve was linear in the range of 37.5$262.5 \mathrm{mg} \mathrm{GAE} / \mathrm{L}\left(\mathrm{R}^{2}=0.9928\right)$ with a standard error of 0.334711 (fig.1).

To measure the total phenols content, $1 \mathrm{~mL}$ volumes of samples were added in $50 \mathrm{~mL}$ calibrated flasks each, then $1 \mathrm{~mL}$ Folin Ciocalteu reagent 1:10 and $1 \mathrm{~mL}$ sodium carbonate solution $20 \%$ were added and the procedure was the same like that used for calibration.

The resulted extractive solution was analysed by an adapted USP30 HPLC method [9] used for separation, identification and quantification of the phenolic compounds as previously described $[10,14]$. The identification and quantitative determination of phenolic compounds was performed using HPLC system (Agilent 1200 ) with quaternary pump, DAD, auto sampler. Separation was carried out on Zorbax Eclipse XDB-C18 column: $250 \mathrm{~mm}, 4.6 \mathrm{~mm}$; $5 \mu \mathrm{m}$ (Agilent Technologies). The flow rate was $1.5 \mathrm{~mL} / \mathrm{min}$, the injection volume was
$20 \mu \mathrm{L}$ and the analysis time took 22 minutes. Quantification of phenolic acids was performed using absorbance measurements at $310 \mathrm{~nm}$ and $35^{\circ} \mathrm{C}$. The retention times and spectra obtained by using diode array detector (DAD) were compared to available authentic standards.

A mixture of standard solutions in $70 \%$ methanol was used having the following concentrations:

$\mathrm{E}$ - resveratrol $=37 \mathrm{mg} / \mathrm{mL}, \mathrm{Z}$ - resveratrol $=0.22 \mathrm{mg} / \mathrm{L}$, caffeic acid $=0.36 \mathrm{mg} / \mathrm{mL}$, chlorogenic acid $=0.37 \mathrm{mg} / \mathrm{mL}$, cinnamic acid $=0.58 \mathrm{mg} / \mathrm{mL}$, vanillin $=0.42 \mathrm{mg} / \mathrm{mL}$, gallic acid $=0.39 \mathrm{mg} / \mathrm{mL}$, ferulic acid $=0.48 \mathrm{mg} / \mathrm{mL}$, 3-0methylgalic acid $=0.34 \mathrm{mg} / \mathrm{mL}$, ellagic acid $=0.43 \mathrm{mg} / \mathrm{mL}$, p-coumaric acid $=0.51 \mathrm{mg} / \mathrm{mL}$.

First, the retention times of standard solutions have been determined (table 1).

The lipid-soluble antioxidant capacity $(A C L)$ was measured by photochemiluminescence method (PLC) using the reagents provided in the ALC kit as per the manufacture's protocol. The ACL assay was performed using Photochem ${ }^{\circledR}$ instrument (Analytic J ena, Germany) against the superoxide anion radicals from luminol, as photosensitizer, upon the UV light [15, 16]. In principle, the lipid-soluble antioxidants from the samples partially eliminate the free radicals and the residual radicals and react with luminol to produce luminescence. The measuring signal (volts) produced by luminescence was traced for specified time duration (120 s).

For the calibration curve, the standard reagent kit, Analytik J ena Standard was used: R1 (dilution solvent Merck ethanol), R2 (buffer reagent), R3 (photosensitizer), R4 (standard solution). The calibration curve was plotted using standard solutions containing 1.0, 2.0, 3.0 and 4.0 nmoles Trolox (R4, Hoffman, La Roche, 6-hydroxy-2,5,7,8tetramethylchroman-2-carboxylic acid). The results were expressed as $\mu$ moles equivalent Trolox/g fresh weight. Measurements were done using $5 \mu \mathrm{L}$ volumes of each undiluted sample and $5 \mu L$ volumes of diluted sample (1:25). ACL value was calculated from the area under the curve at different concentrations. Three individual measurements were performed and the mean value was reported.

Table 1

THE RETENTION TIME OF STANDARDS

\begin{tabular}{|c|c|}
\hline Standard & $\begin{array}{c}\text { Retention time } \pm \\
\mathrm{SD}^{*}, \mathrm{~min} .\end{array}$ \\
\hline gallic acid & $0.990 \pm 0.025$ \\
\hline 3-O-methylgallic acid & $2.606 \pm 0.008$ \\
\hline chlorogenic acid & $3.501 \pm 0.015$ \\
\hline caffeic acid & $4.598 \pm 0.036$ \\
\hline vanillin & $6.919 \pm 0.051$ \\
\hline$p$-coumaric acid & $7.187 \pm 0.019$ \\
\hline feluric acid & $8.565 \pm 0.058$ \\
\hline$E$ - resveratrol & $14.467 \pm 0.017$ \\
\hline ellagic acid & $15.303 \pm 0.027$ \\
\hline$Z$ - resveratrol & $15.751 \pm 0.058$ \\
\hline cinnamic acid & $15.867 \pm 0.007$ \\
\hline (*standard deviation (SD) for six injections)
\end{tabular}




\section{Results and discussions}

Total phenolic content (TPC)

The results of total phenolic content determined for four alcoholic extracts of wild berries versus two alcoholic extract of cultivated berries are presented in table 2 .

The highest result of total phenolic content of was registered for blueberries ( $543.5 \mathrm{mg} / 100 \mathrm{~g}$ f.w.), followed by black cherries, red currants, blackberries and strawberries. The lowest, but still rich, total phenolic content was obtained for raspberries (344.5 mg/100g f.w.). Regarding the total phenolic content of wild berries versus cultivated berries we noticed small difference between the TPC concentration found in black cherries extracts and in blueberries. This fact indicates that wild berries as well

Table 2

TOTAL PHENOLIC CONTENT FROM WILD AND CULTIVATED BERRIESSAMPLES

\begin{tabular}{|l|l|c|}
\hline No. & Sample & $\begin{array}{c}\text { Concentration } \\
\text { (mg GAE } / 100 \mathrm{~g} \text { f.w.) }\end{array}$ \\
\hline 1 & blueberries & 543.5 \\
\hline 2 & raspberries & 344.5 \\
\hline 3 & blackberries & 425.0 \\
\hline 4 & red currants & 432.3 \\
\hline 5 & black cherries & 518.5 \\
\hline 6 & strawberries & 378.2 \\
\hline
\end{tabular}

as cultivated berries are valuable sources of phenolic compounds important for their therapeutically benefits. Phenolic compounds separation, identification and quantification

HPLC - DAD analysis in the ethanolic extracts of studied berries consisted in the identification and quantification of six individual phenolic compounds in different concentrations.

Table 3 presents the individual phenols concentrations determined by HPLC - DAD expressed in $\mathrm{mg} / 100 \mathrm{~g}$ f.w. and percentages (\%).

In blueberries extract there were identified four phenolic acids. Chlorogenic acid and gallic acid have registered high concentrations ( $175.894 \mathrm{mg} / 100 \mathrm{~g}$ f.w., respectively 88.307 $\mathrm{mg} / 100 \mathrm{~g}$ f.w.). On contrary, small quantities of 3-0-methylgallic acid and caffeic acid were measured in blueberries. A similar situation was observed in raspberries extract, where were determined four individual phenolic acids, as gallic acid (178.821 mg/100 g f.w.) and chlorogenic acid (34.916 mg/100g f.w.) in high concentrations while $p$ coumaric acid and 3-0-methyl-gallic acid were in small concentrations.

The strawberries extracthad five individual polyphenolic compounds: chlorogenic acid ( $243.923 \mathrm{mg} / 100 \mathrm{~g}$ f.w.) and gallic acid ( $62.664 \mathrm{mg} / 100 \mathrm{~g} \mathrm{f.w}$.) in high amount, whereas the caffeic acid, 3-0-methyl-gallic acid and cinnamic acid were in small amounts. Five individual polyphenolic compounds there were recorded also in blackberries extract: gallic acid (168.782 mg/100g f.w.), chlorogenic acid ( $30.152 \mathrm{mg} / 100 \mathrm{~g}$ f.w.) in concentrations higher than caffeic acid p-coumaric acid and 3-0-methyl-gallic acid. In the case of red currant extract there were identified and quantified four individual phenolic compounds: gallic acid (169.131 mg/100g f.w.) and chlorogenic acid (30.320 mg/

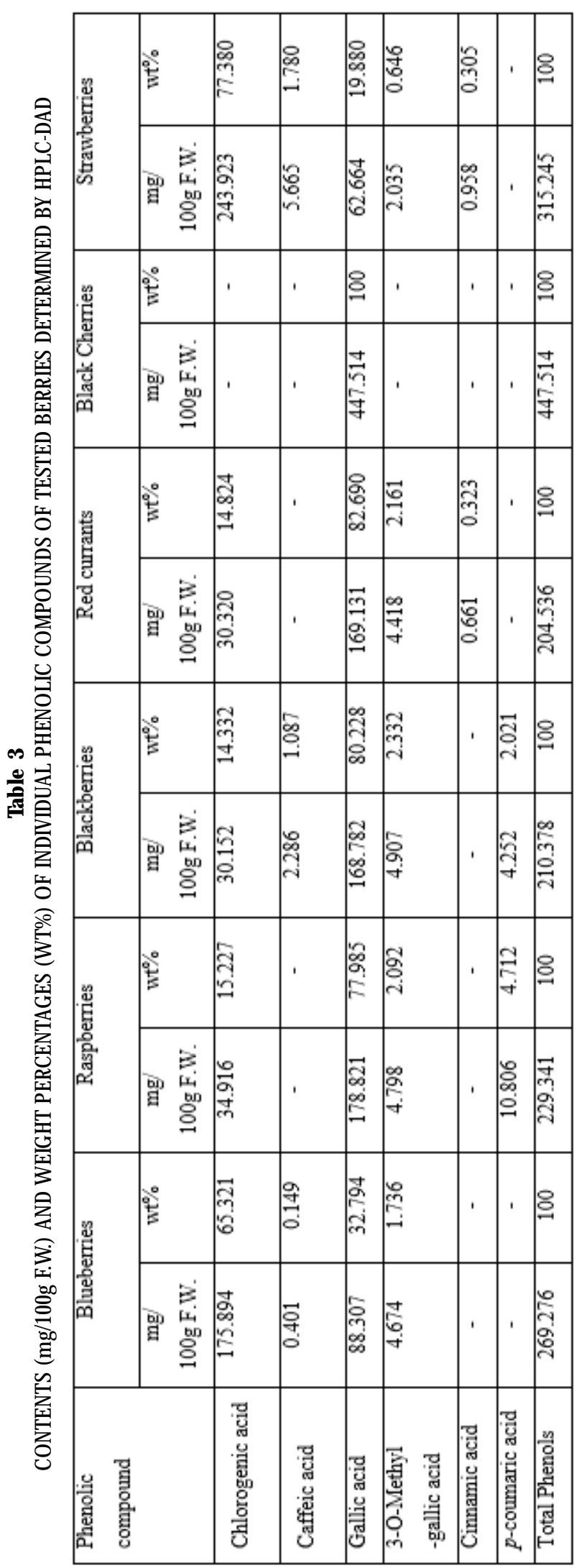

$100 \mathrm{~g} \mathrm{f.w.)}$ in higher amounts than 3-0-methyl-gallic acid and cinnamic acid. The results of HPLC-DAD analyses performed to black cherries extractindicated the presence of only one individual polyphenolic compound: gallic acid; that means that black cherries may contain different phenolic compounds other than the used standards. The highest gallic acid concentration was found in black cherries extract, followed by red currant and blackberries, while the lowest gallic acid concentration was registered for strawberries (62.664 mg/100g f.w.). 
Because of the high concentration of phenolic compounds present in undiluted berries extract a dilution of $1: 25$ was done for all samples. Measurements were performed for $5 \mu \mathrm{L}$ volumes of each undiluted sample and $5 \mathrm{~mL}$ volumes of diluted sample (1:25) (fig. 3).

The highest antioxidant capacity of lipid-soluble phenolic compounds was found in black cherries extract (1152 $\mu$ moles trolox/100 g f.w.), followed by raspberries extract, strawberries extract and red currants extract (table $5)$.

\section{Table 5}

ACL VALUES REGISTERED FOR WILD AND CULTIVATED BERRIES

\begin{tabular}{|l|l|l|l|}
\hline No. & Sample & ACL & ACL \\
& & $\begin{array}{l}\text { (nmoles } \\
\text { Trolox } / \mathrm{mL})\end{array}$ & $/ \mathrm{g}$ f.w.) \\
\hline 1. & blueberries & 6000 & 54.00 \\
\hline 2. & raspberries & 104250 & 938.25 \\
\hline 3. & blackberries & 8082 & 72.74 \\
\hline 4. & red currants & 7150 & 643.5 \\
\hline 5. & black cherries & 128000 & 1152 \\
\hline 6. & strawberries & 74608 & 671.47 \\
\hline
\end{tabular}

The lowest antioxidant capacity of lipid-soluble polyphenolic compounds was found in blueberries (54.00 umoles trolox/100 g f.w.).

Regarding the ACL values for wild versus cultivated berries we notice that black cherries extract present the highest ACL compared to all tested wild berries extracts.

The obtained results are similar with previous published researches concerning the lipid-soluble phenolic compounds ACL in berries [16-20]. The measured analytes concentrations (total phenols, individual polyphenolic acids) and antioxidant capacity of the studied berries alcoholic extracts indicate important ACL values that recommend them as a proper antioxidant source which can be used for special diets and also for its health benefits.

\section{Conclusions}

Characterization of four wild berries (blueberries, blackberries, red currants and raspberries) and two cultivated berries (black cherries and strawberries) alcoholic extracts was done.

The highest total phenolic content determined using molecular absorption spectrometry (modified Folin Ciocalteu method) was registered in blueberries and black cherries, while the lowest was found in raspberries.

HPLC - DAD analysis indicated the presence of six individual polyphenolic compounds in different concentrations: gallic acid exists in all studied berries in variable concentrations ( $62.664-178.821 \mathrm{mg} / 100 \mathrm{~g} \mathrm{f.w}$ ); chlorogenic acid (30.152 - $243.923 \mathrm{mg} / 100 \mathrm{~g}$ f.w.); 3-0methyl-gallic acid (2.035 - $4.907 \mathrm{mg} / 100 \mathrm{~g}$ f.w.); caffeic acid (0.401 - $5.664 \mathrm{mg} / 100 \mathrm{~g}$ f.w.); $p$-coumaric acid (4.252 - $10.806 \mathrm{mg} / 100 \mathrm{~g}$ f.w.) and cinnamic acid (0.661-0.958 $\mathrm{mg} / 100 \mathrm{~g}$ f.w.).
Lipid-soluble antioxidant capacity (ACL), determined by the photochemiluminescence method showed values between 54.00 and 1152 umols trolox/100 g f.w.

Considering the phenolic compounds concentrations found in wild berries (blueberries, blackberries, red currants and raspberries) versus cultivated berries (black cherries and strawberries) we noticed that the highest concentration of total phenolic compounds and $A C L$ values were obtained for black cherries, that recommends them as the highest source of antioxidants from all the tested berries.

The obtained results indicate that all studied berries extracts are rich in antioxidant compounds and can be used in diets or to get health benefits.

\section{References}

1.KAHKONEN, M.P., HOPIA, A.I., VUORELA, H.J ., RAUHA, J .-P., PIHLAJA, K., KUJALA, T.S., HEINONEN, M., J. Agric. Food Chem., 47, 1999, p. 3954.

2.HUANG, W.-Y., ZHANG, H.-C., LIU, W.-X., LI, C.-Y., Zhejiang Univ-Sci B (Biomed \& Biotechnol), 13, no. 2, 2012, p. 94.

3.BRITO, A., ARECHE, C., SEPULVEDA, B., EDWARD J. KENNELLY, E.J ., SIMIRGIOTIS, M.J., Molecules, 19, 2014, p. 10936.

4.GUERRERO, J., CIAMPI, L., CASTILLA, A., MEDEL, F., SCHALCHLI, H., HORMAZABAL, E., BENSCH, E., ALBERDI, M., Chilean J ournal of Agricultural Research 70, no. 4, p. 537.

5.JURIKOVA, T., ROP, O., MLCEK, J., SOCHOR, J., BALLA, S., SZEKERES, L., HEGEDUSOVA, A., HUBALEK, J., ADAM, V., KIZEK, R., Molecules, 17, 2012, p. 61.

6.KIM, M.-B., PARK, J.-S., LIM, S.-B., Food Chemistry, 122, 2010, p. 546.

7.HOMOKI, J.R., NEMES, A., FAZEKAS, E., GYEMANT, G., BALOGH, P., GÁL, F., AL-ASRI, J., MORTIER, J., WOLBER, G., BABINSZKY, L., REMENYIK, J., Food Chemistry, 194, 2016, p. 222.

8.BESCO, E., BRACCIOLI, E., VERTUANI, S., ZIOSI, P., BRAZZO, F., BRUNI, R., SACCHETTI, G., MANFREDINI, S., Food Chemistry, 102, 2007, p. 1352.

9.DOBRINAS, S., STANCIU, G., LUPSOR, S., J. Sci. \& Arts, 2, no. 39, 2017, p. 321.

10.STANCIU, G., CRISTACHE, N., LUPSOR, S., DOBRINAS, S., Rev. Chim. (Bucharest), 68, no. 7, 2017, p. 1429.

11.PALLAG, A., JURCA, T., SIRBU, V., HONIGES, A., JURCA, C., Rev. Chim.(Bucharest), 69, no. 2, 2018, p. 445.

12.TRIFUNSCHI, S., MUNTEANU, M. F., POGURSCHI, E., GLIGOR, R., Rev. Chim. (Bucharest), 68, no. 7, 2017, p. 1677.

13.STANCIU, G., LUPSOR, S., POPESCU, A., OANCEA, A.I., J. Sci. \& Arts, 1, no. 38, 2017, p. 107.

14.POPOV, I. N., LEWIN, G., Photosintesitized Chemiluminiscence. Its Medical and Industrial Applications for Antioxidizability Tests. In: A. M. Garcia-Campana, WRG Baeyens (Eds) Chemiluminiscence in Analytical Chemistry, Marcel Decker Inc., New York, Bassel. 2001.

15.POPOV, I. N., LEWIN, G., Methods in Enzymology, 300, 1999, p. 437. 16.LEAHU, A., OROIAN, M., ROPCIUC, S., Food and Enviroment Safety, 13, no.1, 2014, p. 87.

17.ERKAN, N., AYRANCI, G., AYRANCl, E., Food Chem., 110, 2008, p. 76.(HPLC)

18.DIACONEASA, Z., RANGA, F., RUGINA, D., LEOPOLD, L., POP, O., VODNAR, D., CUIBUS, L., SOCACIU, C., Bulletin UASVM Food Science and Technology, 72, no. 1, 2015, p. 99.

19.BUNEA, A., RUGINA, D.O., PINTEA, A.M., SCONTA, Z., BUNEA, C.I., SOCACIU, C., Not. Bot. Horti. Agrobo., 39, no. 2, 2011, p. 70.

20.BALOGH, E., HEGEDUS, A., STEFANOVITS-BANYAI E., Scientia Horticulturae, 125, 2010, p. 332.

Manuscript received: 3.05 .2018 